\title{
Terminal differentiation is not a major determinant for the success of stem cell therapy - cross-talk between muscle-derived stem cells and host cells
}

\author{
Burhan Gharaibeh'1,2, Mitra Lavasani', James H Cummins and Johnny Huard ${ }^{1,2,3, *}$
}

\begin{abstract}
We have found that when muscle-derived stem cells (MDSCs) are implanted into a variety of tissues only a small fraction of the donor cells can be found within the regenerated tissues and the vast majority of cells are host derived. This observation has also been documented by other investigators using a variety of different stem cell types. It is speculated that the transplanted stem cells release factors that modulate repair indirectly by mobilizing the host's cells and attracting them to the injury site in a paracrine manner. This process is loosely called a'paracrine mechanism', but its effects are not necessarily restricted to the injury site. In support of this speculation, it has been reported that increasing angiogenesis leads to an improvement of cardiac function, while inhibiting angiogenesis reduces the regeneration capacity of the stem cells in the injured vascularized tissues. This observation supports the finding that most of the cells that contribute to the repair process are indeed chemo-attracted to the injury site, potentially through host neo-angiogenesis. Since it has recently been observed that cells residing within the walls of blood vessels (endothelial cells and pericytes) appear to represent an origin for post-natal stem cells, it is tempting to hypothesize that the promotion of tissue repair, via neo-angiogenesis, involves these blood vesselderived stem cells. For non-vascularized tissues, such as articular cartilage, the regenerative property of the injected stem cells still promotes a paracrine, or bystander, effect, which involves the resident cells found within the injured microenvironment, albeit not through the promotion of angiogenesis. In this paper, we review the current knowledge of post-natal stem cell therapy and demonstrate the influence that implanted stem cells have on the tissue regeneration and repair process. We argue that the terminal differentiation capacity of implanted stem cells is not the major determinant of the cells regenerative potential and that the paracrine effect imparted by the transplanted cells plays a greater role in the regeneration process.
\end{abstract}

\section{Introduction}

Our research group has isolated, by a modified preplate technique $[1,2]$, a population of muscle-derived stem cells (MDSCs) from murine post-natal skeletal muscle. These MDSCs were shown to have the ability to proliferate in vivo for an extended period of time and the capacity to self-renew, and to undergo multilineage differentiation in vitro and in vivo [2]. Current knowledge on the utility of MDSCs for enhancing repair in various musculoskeletal tissues and injured cardiac muscle and the potential for their use in clinical applications is

*Correspondence: jhuard@pitt.edu

'Stem Cell Research Center, Department of Orthopaedic Surgery, University of

Pittsburgh, Pittsburgh, PA 15219, USA

Full list of author information is available at the end of the article reviewed in several publications [3-5]. Our data show that these cells display a high transplantation capacity in skeletal muscle and exhibit only limited degrees of engraftment capacity in cardiac, bone, cartilage, and nerve tissues in respective animal model injuries. Their success in repairing damaged tissues is attributed, at least in part, to their resistance to stress and through the paracrine effect that they impart on host tissues. These paracrine effects can stimulate the mobilization of host progenitor cells, stimulate the production of new blood vessels via neoangiogenesis, and possibly modulate the host immune response.

The term paracrine mechanism, used herein, refers to effects that are not necessarily limited to the injury site but occur throughout the organism. In this review, we focus on studies involving MDSCs in enhancing repair and improving function in injured heart muscle and promoting repair of osteochondral defects in articular 
cartilage (AC), and explore the possibility that the repair is induced by host cell recruitment, angiogenic and/or anti-inflammatory activities, and not necessarily restricted to the differentiation of the implanted cells in host tissue.

\section{Stem cell-mediated therapies for cardiac injuries}

Cellular cardiomyoplasty (CCM), cell transplantation for cardiac repair, is an alternative therapeutic approach for the treatment of congestive heart failure [6,7]. Researchers have used a wide variety of cell types for CCM, including embryonic and neonatal rodent and porcine cardiomyocytes, fetal smooth muscle cells, AT-1 tumor cardiomyocytes, human adult and fetal cardiomyocytes, autologous adult atrial cells, and dermal fibroblasts [8-19]. Researchers have also identified more suitable donor cells for CCM. The most promising cell populations evaluated to date include skeletal muscle myoblasts [20-23], murine embryonic stem cells [24,25], bone marrow (BM)-derived stem cells, mesenchymal stem cells (MSCs) [17,26-28], purified (enriched) hematopoietic stem cells [29-31], blood- and BM-derived endothelial progenitor cells [3235], and cardiac stem cells [36-40]. To date, donor cell populations used in CCM have demonstrated some beneficial effects for the heart, but various ethical, biological, and technical concerns limit their suitability for use in human patients. Segers and Lee [41] and Gersh et al. [42] reviewed reports on randomized and controlled studies in a large number of patients treated with different cell therapeutic strategies (autologous, natural, or bioengineered cell populations) and the modes of cell injection, and provided an evaluation of their suitability for clinical use. Other reports have summarized findings on CCM in animal models and clinical reports [41,43-44].

Promising data have been generated recently when skeletal muscle myoblasts were utilized in several CCM human trials $[45,46]$. The cells were transplanted via direct intramyocardial injection and intra-arterial injection [21-23,47-49] and despite the ability of the engrafted skeletal myoblasts to adapt to the cardiac microenvironment and improve cardiac performance in experimental animal models of cardiac injury [21,22,46-50], various limitations, including poor cell survival - similar to those encountered with myoblast transplantation into skeletal muscle - have hindered the overall applicability of this therapeutic approach [51-53].

Our group has used MDSCs in cardiac transplantation experiments, which display an improved transplantation capacity when compared with myoblasts. MDSC engraftment was 25-fold higher than myoblasts in diseased hearts (with a mean of 53 donor MDSCs versus 2 donor myoblasts found within the injected hearts at 12 weeks post-injection) [54]. Importantly, they elicited significant improvements in cardiac function by exhibiting superior cell survival and improving angiogenesis [54-56], most likely due to their secretion of vascular endothelial growth factor (VEGF) [57].

Although the exact origin of mouse MDSCs remains to be determined, these cells express the endothelial cell marker von Willebrand factor and can spontaneously participate in blood vessel formation after being injected into skeletal and cardiac muscle [58]. Their participation in blood vessel formation appears to be due to their expression of VEGF and by the fact that they can also differentiate toward an endothelial cell lineage $[2,54]$. The latter results suggest that a relationship exists between mouse MDSCs and endothelial cells. Other types of stem cells derived from the walls of blood vessels, including mesoangioblasts and perivascular cells, appear to share similarities with MDSCs, which also supports our hypothesis that a relationship exists between MDSCs and endothelial cells. We have also isolated several populations of muscle-derived cells from human skeletal muscle by fluorescence-activated cell sorting (FACS) that coexpress myogenic (CD56 and Pax7) and endothelial cell markers (CD34, von Willebrand factor, ulex, and VEcadherin) both in vitro and in vivo [59-61]. We observed that certain types of cells that constitute the walls of blood vessels in adult human muscle (endothelial cells, myo-endothelial cells, and pericytes) appear to be very early myogenic progenitor cells that have high myogenic potential, and regenerative capacities in both skeletal and cardiac muscles [59,61-63], much like that exhibited by murine MDSCs [2]. We have recently observed that a greater improvement in left ventricular function was observed after the intramyocardial injection of myoendothelial cells when compared to hearts injected with myoblasts [63]. Transplanted myo-endothelial cells generated relatively good engraftments within the infarcted myocardium and also stimulated angiogenesis, attenuated scar tissue formation, and supported the proliferation and survival of endogenous cardiomyocytes more effectively than transplanted myoblasts or endothelial cells [63]. In a different set of preliminary studies, we also observed that the injured hearts injected with skeletal muscle-derived pericytes displayed significant improvements in cardiac contraction, greater neoangiogenesis, and a significant reduction in scar area formation when compared with hearts injected with phosphate-buffered saline [64].

These latter findings suggest that myo-endothelial cells and pericytes likely represent the human counterpart to murine MDSCs and consequently comprise a potential therapeutic cell source that could provide valuable benefits for patients suffering from myocardial infarction [64]. We have observed that after the implantation of murine MDSCs and human muscle-derived cells 
(myo-endothelial cells and pericytes), the induction of heart repair is mediated mostly by the host cells. Indeed, we have observed that only a small fraction of the donor cells can actually be found within the regenerated heart tissue, indicating that the host cells must be largely contributing to the cardiac repair process $[54,63]$. These results indicate that the injected cells may act as a reservoir of secreting molecules that play a role in the repair process without actively differentiating toward a cardiomyocyte lineage or by fusing with host cardiac cells.

The cell-mediated paracrine and bystander effects on cardiac repair have also been observed with other stem cell types, including BM-derived cell populations [65-69], hematopoietic cells [70], adipose-derived stem cells [71], endothelial progenitor cells [72], human blood endothelial cells [73], and kidney-derived MSCs [74]. These reports support the hypothesis that the beneficial effect seen with MDSCs is likely due to the increased secretion of paracrine factors and not primarily due to the differentiation capacity of the donor cells toward a cardiac phenotype (for reviews refer to $[28,75]$ ), especially since the cardiac differentiation of these stem cells after implantation remains extremely low (Table 1).

In support of this paracrine effect hypothesis, we previously reported that inhibiting angiogenesis by injecting genetically manipulated MDSCs that express the anti-angiogenic protein sFlt-1 reduces the regeneration capacity of MDSCs in injured heart. The findings of this study demonstrated that most of the cells contributing to the repair process were indeed chemo-attracted to the injury site by the injected cells [57]. Although the paracrine action of the donor stem cells is widely accepted, the origin of the host cells that participate in the repair process remains largely unknown. Further experiments are underway to determine the type of cells and their origins. Likely candidates for the host cells involved in the repair process include, but are not limited to, BM-derived cells, vascular-derived endothelial progenitor cells, inflammatory cells and resident tissue stem cells. Since it is well established that the vascular supply plays a major role in cardiac tissue repair, it is logical to speculate that blood vessel-derived cells are also involved in the repair process after cardiac injury. Indeed, it has already been shown [76-78] in other animal injury models that tissue repair induces the mobilization and incorporation of BM-derived endothelial progenitor cells, suggesting that some of the chemo-attracted host cells are perhaps derived from endothelial progenitor cells. It is important to bear in mind that promoting angiogenesis will bring more blood vessel-derived cells to the injury area, but also cells derived from the BM and bloodstream; therefore, caution needs be taken when reporting these research findings.
These results with MDSCs and other stem cell types (Table 1) strongly support the fact that a stem cell's multipotent capacity - in this case the ability to differentiate into a cardiac lineage - is not a pre-requisite for the cell's ability to readily aid in the repair of an injured heart. We cannot exclude that a stem cell's ability to readily undergo cardiac differentiation does not provide additional beneficial effect for cardiac repair; however, this still remains to be verified experimentally. More importantly, we have observed that the ability of MDSCs to resist environmental stresses, including oxidative and inflammatory stresses, through the cells' high antioxidant capacity (via glutathione and superoxide dismutase), plays a major role in the high regenerative capacity of MDSCs in various tissues, including the heart $[79,80]$. Moreover, we have observed that treating MDSCs with the reducing agent glutathione significantly reduced their ability to repair the heart, supporting our driving hypothesis that a cell's ability to survive within the injured tissue is more important than its terminal differentiation potential [79]. A population of stem cells that could survive better in this type of harsh environment could enhance the regeneration process, potentially through an increase in their paracrine effect (for example, increased angiogenesis).

A recent study showed that preconditioning BMderived MSCs prior to their transplantation enhanced their capacity to repair infarcted myocardium, which was attributable to an improvement of donor cell survival and an increase in angiogenesis/vascularization and proangiogenic factors [81]. In addition, Pasha et al. [82] reported that preconditioning cells with the chemokine stromal-derived factor 1 alpha (SDF-1) could significantly enhance BM-derived MSC survival, vascular density, engraftment, and myocardial function [82]. MSCs derived from adult $\mathrm{BM}$ genetically modified with the antiapoptotic gene $B c l-2$ enhanced cell survival, engraftment, revascularization, and functional improvement in a rat left anterior descending ligation model of myocardial infarction via an intracardiac injection [83]. Taken together, these results suggest that a cell's ability to survive the harsh microenvironment within the injured heart represents a major determinant for its regenerative capacity. Surviving cells can eventually promote the repair process primarily through a paracrine effect that involves angiogenesis, especially for cardiac repair (Figure 1).

Finally, it is important to state that stem cells with cardiomyocyte properties (such as cardiac stem cells, embryonic stem cells or genetically engineered cells with cardiomyocyte inducers) are perhaps more likely to terminally differentiate into cardiomyocytes and participate in heart repair than stem cells incapable of differentiating toward a cardiac lineage. It is possible that 


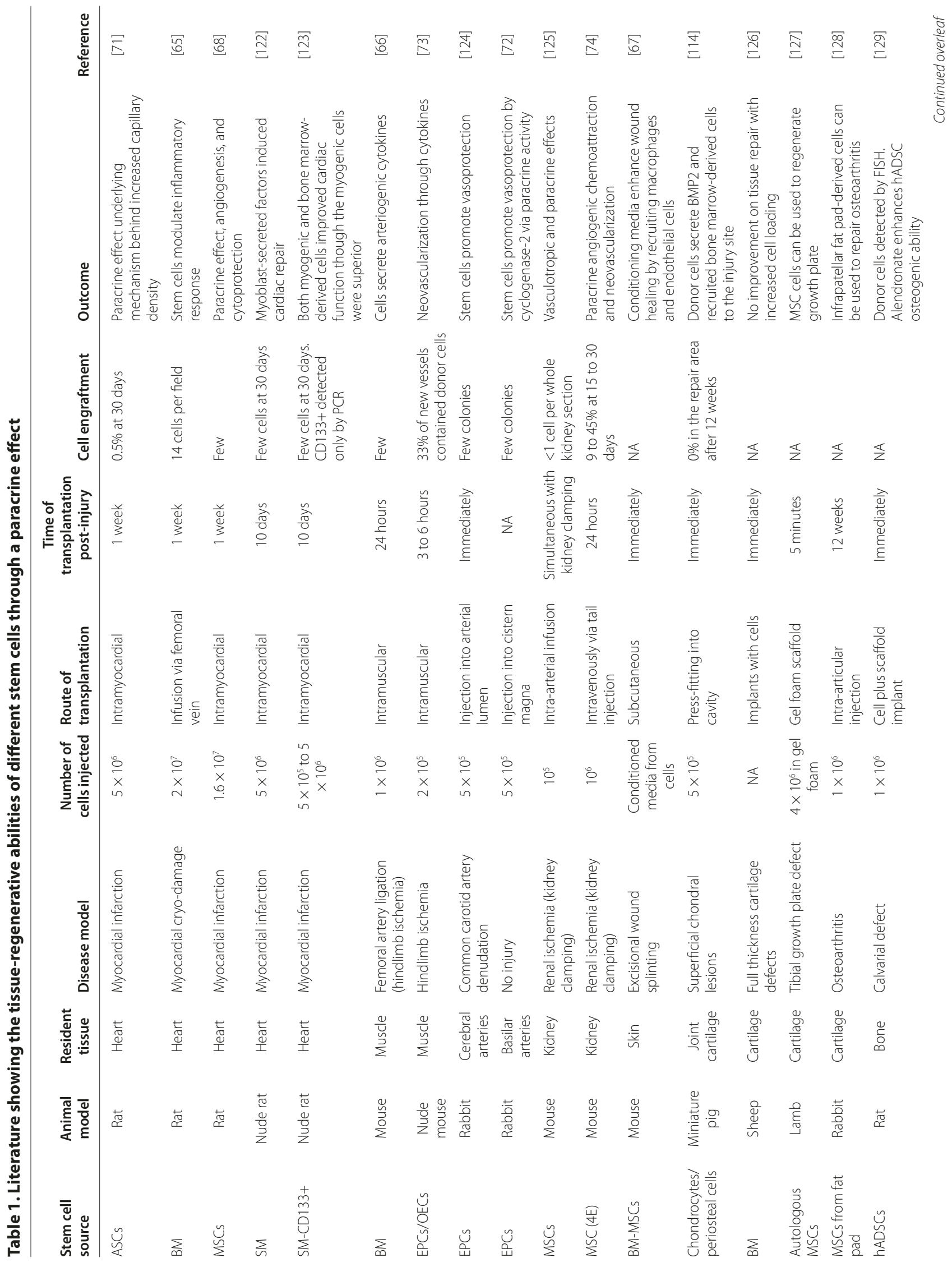


cardiac differentiation of stem cells prior to their transplantation could improve cardiac function due to their ability to integrate more effectively with the host myocardium. It will also be important to determine whether differentiating the cells toward a cardiac lineage prior to their implantation could influence the paracrine effect of the stem cells and how this would influence their action in the cardiac repair process. Thus far, however, from our observations and reports in the literature (Table 1), very few post-natal stem cells have been shown to adopt a cardiomyocyte phenotype, yet the vast majority of transplanted stem cell types have been shown to improve cardiac function.

\section{Stem cell therapy for articular cartilage repair}

In this section, we investigate the paracrine effect of stem cell therapy in the AC repair process of osteoarthritis (OA), where the cells used (MDSCs) have the ability to undergo chondrogenic differentiation but the paracrine effect of the donor cells on the promotion of angiogenesis is not required, but, in fact, needs to be inhibited. Therefore, it is important to determine, in this situation, whether the paracrine effect of the stem cells on the local microenvironment also plays a major role in the regenerative capacity of the stem cells for AC repair, without relying on angiogenic-related cells (blood vesseland circulation-derived stem cells).

$\mathrm{OA}$ is a chronic degenerative joint disorder with worldwide impact that is primarily characterized by $\mathrm{AC}$ destruction and osteophyte formation. One of the chief mediators of $\mathrm{OA}$ is inflammation and angiogenesis. Yin and Pacifici [84] demonstrated that VEGF treatment during early limb bud development in chick embryos causes excess vascularization and consequently reduced condensation of the chondrogenic mesenchyme. In the growth plate, VEGF has been reported to play an essential role in cartilage vascularization and absorption of hypertrophic chondrocytes, which together lead to endochondral ossification [85-87]. On the other hand, when VEGF was blocked with the soluble receptor protein (sFlt-1), it led to the expansion of a zone of hypertrophic cartilage and the inhibition of cartilage resorption [86]. Similar to endochondral ossification, osteophyte formation during OA development has been reported to involve VEGF signaling [88]. For an extensive review on the relationship between angiogenesis and $\mathrm{OA}$ in humans and animal model studies, we refer our readers to the review by Ashraf and Walsh [89], who outlined the complexity of $\mathrm{OA}$ and the interrelationship between angiogenesis, inflammatory processes, damage, innervation, and pain perception in the joint.

Recent data reveal that the expression of VEGF and its receptors (Flt1 and Flk1) in osteoarthritic cartilage reflects the ability of VEGF to enhance catabolic 


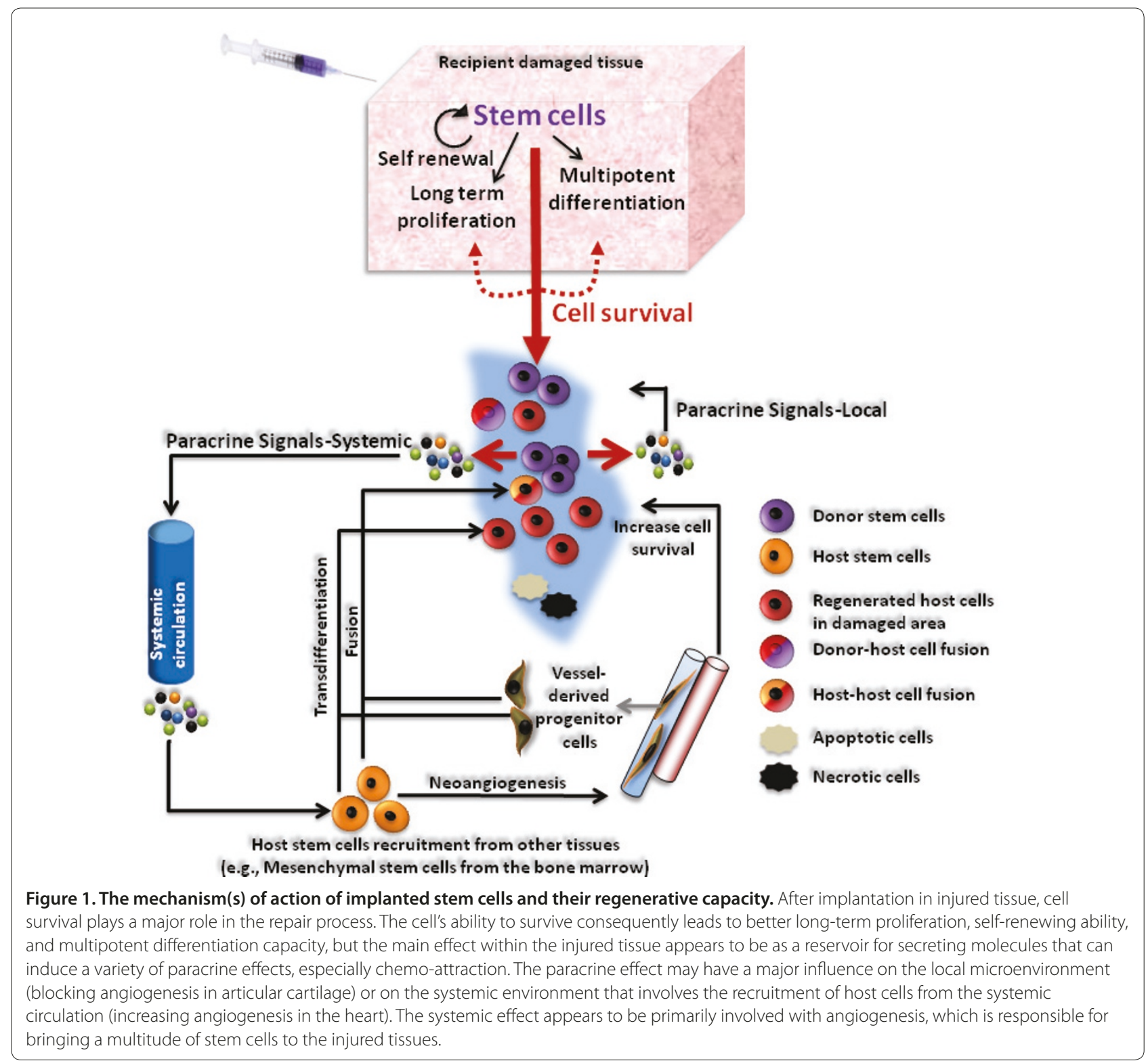

pathways in chondrocytes by stimulating matrix metalloproteinase activity and reducing tissue inhibitors of matrix metalloproteinases (TIMPs) [90-93]. These data suggest that, apart from the effect of VEGF on cartilage vascularization and proliferation of cells in the synovial membrane, chondrocyte-derived VEGF promotes catabolic pathways in the cartilage itself, thereby leading to a progressive breakdown of the $\mathrm{AC}$ extracellular matrix.

Since AC is a tissue type that is poorly supplied by blood vessels (avascular), nerves, and the lymphatic system, it has a very limited capacity for repair after injury. Although several therapies have been used to treat OA, no widely accepted treatments have been established, with the exception of arthroplasty. For this reason, tissue engineering techniques aimed at repairing $\mathrm{AC}$ have been extensively studied and chondrocyte transplantation is currently performed in clinics [94-96]. The current most effective OA treatment, besides arthroplasty, is the use of autologous chondrocyte transplantation. However, this treatment has several limitations, including the use of neighboring healthy donor cartilage, difficulty in treating large-scale defects, limited expansion capacity of the primary chondrocytes, the need for a periosteal patch to maintain engineered cartilage, and the fact that, in most cases, only 30 to $40 \%$ of the defect regenerates AC, with the remaining defect being filled with fibrocartilage [97-99]. In light of these limitations, it is important to find other sources of cells that are abundant and capable of chondrogenic differentiation. Stem cells are more attractive than primary chondrocytes because of their 
superior capacity for self-renewal, proliferation, and survival following microenvironmental stress. Recently, stem cell-based therapies have been used clinically for cartilage repair $[100,101]$. Several studies have suggested that stem cells can undergo chondrogenesis and repair $\mathrm{AC}$ in experimental cartilage injury models (osteochondral lesions), including studies using MDSCs [102]. We have already reported that bone morphogenetic protein (BMP)4-transduced MDSCs improve cartilage regeneration in in vitro pellet cultures and in an in vivo cartilage defect model (osteochondral defect) [102]. We have also shown recently that human muscle-derived cells (myo-endothelial cells and pericytes) can undergo chondrogenic differentiation in vitro, albeit to a different extent [61,62].

Since the expression of VEGF by chondrocytes in the osteoarthritic joint has been related to cartilage destruction $[88,90,91,93,103-105]$ and the induction of arthritis (especially when the dosage reached a certain threshold) [106-108], it is likely that blocking VEGF would prove to be a beneficial means of preventing or delaying the progression of OA. This hypothesis was recently supported by the fact that treatment with sFlt-1 (a VEGF antagonist) decreased the severity of arthritis in a murine model $[86,109,110]$ and our recent observation that the injection of MDSCs expressing both BMP4 and sFlt-1 improved AC repair in a more effective manner than MDSCs expressing just BMP4 [111,112]. Our results suggest that sFlt-1/BMP4-transduced MDSCs, which were transplanted intra-capsularly into an OA rat model, enhanced AC regeneration via BMP4's autocrine/ paracrine effects, and contributed to an appropriate environment that prevented chondrocyte apoptosis by blocking the intrinsic VEGF catabolic pathway and by extrinsic VEGF-induced vascular invasion. Treatment of MDSCs with sFlt- 1 and BMP4 combined is potentially an effective therapy for OA repair that may improve the quality and persistence of regenerated AC [111]. Since the cells were injected into the joint fluid, most of the injected cells do not primarily contribute to the regeneration of the AC through their differentiation into chondrocytes; instead, they chemo-attract host cells to the injury site, which are the cells primarily seen in the regenerated tissue. We are performing experiments to determine the origin of these host cells that participate in the repair process by testing the role of inflammatory/immune, BM and synovial cells. Since we have observed that the injection of muscle-derived cells (isolated from rabbit skeletal muscle) in the joint fluid of rabbits leads to a massive attachment of the injected cells in the synovium [113], we posit that synovium-derived cells are implicated in the repair process.

Although the mechanism behind the beneficial effect of blocking angiogenesis in AC repair is still not fully elucidated, these results highlight the importance of controlling the local microenvironment by reducing angiogenesis. Therefore, the reduction of angiogenesis eliminates the mobilization of blood vessel wall- and circulation-derived progenitor cells and thus their recruitment and differentiation toward a chondrogenic lineage, which demonstrates the paracrine effect that the implanted stem cells exert on the local microenvironment for optimizing the $\mathrm{AC}$ repair process (Figure 1).

Recently, Gelse and colleagues [114] reported that transplanted rib chondrocyte spheroids could repair a cartilage defect in a miniature pig model by producing BMP2 and attracting the host's BM-derived cells. The transplanted chondrocyte spheroids provided a stimulatory paracrine effect that induced the in-growth and chondrogenic ability of the host BM-derived cells. This paracrine effect was observed to be far more important to the repair process than the direct differentiation of the transplanted cells into chondrocytes. Although the transplanted cells enhanced the tissue repair process, these experiments further validate our hypothesis that the AC repair process, even using stem cells other than MDSCs, also relies on the paracrine effect that the donor cells impart on the host cells.

\section{The microenvironment influences the fate of stem cells}

BMP4-transduced MDSCs can undergo osteogenesis and promote bone repair when injected into a bone defect [115-117], which is difficult to explain given that similar BMP4-transduced cells can promote the repair of AC when injected into an osteochondral defect. This phenomenon, however, is a good example of how the microenvironment influences the regenerative ability of the transplanted stem cells. After a bone or AC injury occurs, a multitude of signals are released at the site of injury. It is likely that the chemotaxis of host cells is enhanced by growth factors and cytokines produced by the donor cells, which are in turn affected by their interaction with the extracellular matrix at the injury site. Speculatively, stem cells injected into the site could aid and enhance the mediation of the repair process; however, knowing that the repair process relies primarily on host cell participation, it is easier to understand why BMP4-expressing MDSCs have a beneficial effect on both bone and $\mathrm{AC}$ repair since the repair process does not rely on the terminal differentiation of the donor cells per se. Furthermore, Blanke et al. [118] have shown that successful repair of cartilaginous tissue after transplantation of chondrocytes was associated with their production of thrombospondin-1 and chondromodulin-I anti-angiogenic proteins. They found that tissues resisted ossification when the chondrocytes produced detectable levels of anti-angiogenic proteins, 
which counteracted the angiogenic activity of endothelial cells. It is very likely that MDSCs react in a similar manner to the local environmental cues and produce anti-angiogenic proteins similar to thrombospondin-1 and chondromodulin-I when in a cartilaginous microenvironment, a hypothesis that will need to be further investigated in future studies.

Another example that demonstrates the influence of the microenvironment is the fact that the regenerative capacity of stem cells has been shown to be influenced by the age of both the host- and the donor-derived stem cells [119]. The results showed the rejuvenation of aged progenitor cells after their exposure to a young systemic environment where a young and aged mouse had their circulatory systems linked by heterochronic parabiosis. These findings highly implied that the proliferative property of satellite cells obtained from old mice is restored after incubation with the serum from a young animal. These results further support our hypothesis that the regenerative process of given stem cells is strongly influenced by signals found within the microenvironment.

Furthermore, we have recently observed that the regenerative capacity of stem cells also appears to be influenced by the gender of the donor cells and the host. In fact, we reported that female MDSCs are more myogenic and can promote muscle regeneration in a more effective manner than male MDSCs [120]. On the other hand, male MDSCs were shown to be more osteogenic and chondrogenic and promoted both bone and $\mathrm{AC}$ repair in a more effective manner than their female counterparts $[111,121]$. Although the mechanisms behind these gender differences are still unclear, we have shown that the host microenvironment is also influenced by the gender of the animal and plays a role in the efficiency of the repair process. Indeed, we have reported that bone formation mediated by male MDSCs is superior in a male host versus that of a female host [121]. Interestingly, female MDSCs produce better bone when injected into a male host when compared to a female host. These results further support our hypothesis that the microenvironment influences the fate and regenerative potential of the injected stem cells.

\section{Conclusion}

Although it has been speculated for numerous years that the high regenerative potential of stem cells is due to their terminal differentiation capacity, current findings appear to indicate that very few donor cells actually differentiate and participate in the regeneration of these injured tissues; instead, the vast majority of the cells reconstituting the regenerated tissues are host-derived. These findings are further supported by recent results showing that when the paracrine signaling of the implanted stem cells is interrupted (that is, by blocking
VEGF and angiogenesis), there is a reduction in the regeneration and repair capacity of the injured tissues, as is the case for cardiac muscle repair. Although it is still unclear which host cells are involved in the repair processes after stem cell transplantation, blood vessel cells, immune and inflammatory cells and resident cells at the site of the injury (especially for AC damage), appear to play a role in the regeneration/repair process. It is quite clear, however, that the terminal differentiation of stem cells does not represent a major determinant for the success of stem cell therapy; instead, it appears that donor cell survival and the cells' paracrine effect play much more critical roles in the success of stem cell therapy. This finding challenges current dogma indicating that embryonic stem cells may have an advantage over adult-derived stem cells because of their higher level of multipotentiality. We therefore put forward the proposition that it is the stem cell's superior cell survival capacity that leads to its increased ability to chemoattract host cells through the secretion of certain growth factors and chemokines and this is the key important feature for successful stem cell therapy, more so than stem cells' terminal differentiation capacity.

\section{Future directions}

The paradigm shift in evaluating stem cell engraftment based on their terminal differentiation into host cells underscores the need to understand the biology of stem cells to fully utilize their potential. Furthermore, we are increasingly aware that stem cells alone are not sufficient for a long lasting regenerative effect. The ultimate goal would thus be the generation of tissues incorporating stem cells, scaffolds and biological materials that permit communication with host tissues, allowing optimal remodeling and improved functionality. Future regenerative schemes may include cells and a complex milieu of factors based on a rigorous understanding of stem cells' paracrine secretions. Computer-aided bioreactors, bioprinters, artificial or decellularized organs and other biodevices could also benefit from knowledge of stem cells' paracrine activities.

\section{Abbreviations \\ AC, articular cartilage; BM, bone marrow; BMP, bone morphogenetic protein; CCM, cellular cardiomyoplasty; MDSC, muscle-derived stem cell; MSC, mesenchymal stem cell; OA, osteoarthritis; $\mathrm{VEGF}$, vascular endothelial growth factor. \\ Competing interests \\ $\mathrm{JH}$ has received remuneration as a consultant from Cook MyoSite Inc., Pittsburgh, USA over the past 5 years, the other authors declare that they have no competing interests.}

\section{Acknowledgements}

This work was supported in part by a Department of Defense Contract (W81XWH-08-0076), the National Institute of Health (RO1 DE013420-09), the William F and Jean W Donaldson Chair at the Children's Hospital of Pittsburgh, the Henry J Mankin Endowed Chair in Orthopaedic Surgery at the University 
of Pittsburgh and the Orris C Hirtzel and Beatrice Dewey Hirtzel Memorial Foundation.

\section{Author details}

'Stem Cell Research Center, Department of Orthopaedic Surgery, University of Pittsburgh, Pittsburgh, PA 15219, USA. ²Department of Bioengineering, University of Pittsburgh, Pittsburgh, PA 15219, USA. ${ }^{3}$ Departments of Molecular Genetics and Biochemistry, Physical Medicine and Rehabilitation, and Pathology, University of Pittsburgh, Pittsburgh, PA 15219, USA.

Published: 8 July 2011

\section{References}

1. Gharaibeh B, Lu A, Tebbets J, Zheng B, Feduska J, Crisan M, Péault B, Cummins J, Huard J: Isolation of a slowly adhering cell fraction containing stem cells from murine skeletal muscle by the preplate technique. Nat Protoc 2008, 3:1501-1509.

2. Qu-Petersen Z, Deasy B, Jankowski R, Ikezawa M, Cummins J, Pruchnic R, Mytinger J, Cao B, Gates C, Wernig A, Huard J: Identification of a novel population of muscle stem cells in mice: potential for muscle regeneration. J Cell Biol 2002, 157:851-864.

3. Gharaibeh B, Drowley L, Huard J: Muscle-derived stem cells: a model for stem cell therapy in regenerative medicine. In Stem Cells and Regenerative Medicine. Edited by Appasani K, Appasani RK. New York: Humana Press; 2011:565-578.

4. Usas A, Huard J: Muscle-derived stem cells for tissue engineering and regenerative therapy. Biomaterials 2007, 28:5401-5406.

5. Huard J, Gharaibeh B, Usas A: Regenerative medicine based on musclederived stem cells. Operative Techniques Orthopaedics 2010, 20:119-126.

6. Caplice NM, Gersh BJ, Alegria JR: Cell therapy for cardiovascular disease: what cells, what diseases and for whom? Nat Clin Pract Cardiovasc Med 2005, 2:37-43.

7. Laflamme MA, Murry CE: Regenerating the heart. Nat Biotechno/ 2005, 23:845-856

8. Rangappa S, Makkar R, Forrester J: Review article: current status of myocardial regeneration: new cell sources and new strategies. J Cardiovasc Pharmacol Ther 2010, 15:338-343.

9. Etzion S, Battler A, Barbash IM, Cagnano E, Zarin P, Granot Y, Kedes LH, Klone RA, Leor J: Influence of embryonic cardiomyocyte transplantation on the progression of heart failure in a rat model of extensive myocardial infarction. J Mol Cell Cardiol 2001, 33:1321-1330.

10. Leor J, Patterson M, Quinones MJ, Kedes LH, Kloner RA: Transplantation of fetal myocardial tissue into the infarcted myocardium of rat. A potential method for repair of infarcted myocardium? Circulation 1996, 94(9 Suppl):॥332-336.

11. Li RK, Jia ZQ, Weisel RD, Mickle DA, Zhang J, Mohabeer MK, Rao V, Ivanov J: Cardiomyocyte transplantation improves heart function. Ann Thorac Surg 1996, 62:654-660; discussion 660-661

12. Reinecke $H$, Zhang M, Bartosek T, Murry CE: Survival, integration, and differentiation of cardiomyocyte grafts: a study in normal and injured rat hearts. Circulation 1999, 100:193-202.

13. Watanabe E, Smith DM Jr, Delcarpio JB, Sun J, Smart FW, Van Meter CH Jr, Claycomb WC: Cardiomyocyte transplantation in a porcine myocardial infarction model. Cell Transplant 1998, 7:239-246.

14. Li RK, Jia ZQ, Weisel RD, Merante F, Mickle DA: Smooth muscle cell transplantation into myocardial scar tissue improves heart function. $J \mathrm{Mol}$ Cell Cardiol 1999, 31:513-522

15. Koh GY, Soonpaa MH, Klug MG, Field LJ: Long-term survival of AT-1 cardiomyocyte grafts in syngeneic myocardium. Am J Physiol 1993 264:H1727-1733.

16. Van Meter CH Jr, Claycomb WC, Delcarpio JB, Smith DM, deGruiter H, Smart F, Ochsner $\mathrm{J}$ : Myoblast transplantation in the porcine model: a potential technique for myocardial repair. J Thorac Cardiovasc Surg 1995, 110:1442-1448.

17. Sakai T, Li RK, Weisel RD, Mickle DA, Kim EJ, Tomita S, Jia ZQ, Yau TM: Autologous heart cell transplantation improves cardiac function after myocardial injury. Ann Thorac Surg 1999, 68:2074-2080; discussion 2080-2081.

18. Hutcheson KA, Atkins BZ, Hueman MT, Hopkins MB, Glower DD, Taylor DA: Comparison of benefits on myocardial performance of cellular cardiomyoplasty with skeletal myoblasts and fibroblasts. Cell Transplant
2000, 9:359-368

19. Li RK, Yau TM, Weisel RD, Mickle DA, Sakai T, Choi A, Jia ZQ: Construction of a bioengineered cardiac graft. J Thorac Cardiovasc Surg 2000, 119:368-375.

20. Tamaki T, Akatsuka A, Okada Y, Uchiyama Y, Tono K, Wada M, Hoshi A, Iwaguro H, Iwasaki H, Oyamada A, Asahara T: Cardiomyocyte formation by skeletal muscle-derived multi-myogenic stem cells after transplantation into infarcted myocardium. PLOS ONE 2008, 3:e1789.

21. Kessler PD, Byrne BJ: Myoblast cell grafting into heart muscle: cellular biology and potential applications. Annu Rev Physiol 1999, 61:219-242.

22. Taylor DA, Atkins BZ, Hungspreugs P, Jones TR, Reedy MC, Hutcheson KA, Glower DD, Kraus WE: Regenerating functional myocardium: improved performance after skeletal myoblast transplantation. Nat Med 1998, 4:929-933.

23. Salmons S: Cardiac assistance from skeletal muscle: a reappraisal. Eur J Cardiothorac Surg 2009, 35:204-213.

24. Klug MG, Soonpaa MH, Koh GY, Field LJ: Genetically selected cardiomyocytes from differentiating embronic stem cells form stable intracardiac grafts. J Clin Invest 1996, 98:216-224.

25. Min JY, Yang Y, Converso KL, Liu L, Huang Q, Morgan JP, Xiao YF: Transplantation of embryonic stem cells improves cardiac function in postinfarcted rats. J Appl Physiol 2002, 92:288-296.

26. Paul D, Samuel SM, Maulik N: Mesenchymal stem cell: present challenges and prospective cellular cardiomyoplasty approaches for myocardial regeneration. Antioxid Redox Signal 2009, 11:1841-1855.

27. Wang JS, Shum-Tim D, Chedrawy E, Chiu RC: The coronary delivery of marrow stromal cells for myocardial regeneration: pathophysiologic and therapeutic implications. J Thorac Cardiovasc Surg 2001, 122:699-705.

28. Gnecchi M, He H, Liang OD, Melo LG, Morello F, Mu H, Noiseux N, Zhang L, Pratt RE, Ingwall JS, Dzau VJ: Paracrine action accounts for marked protection of ischemic heart by Akt-modified mesenchymal stem cells. Nat Med 2005, 11:367-368.

29. Hirschi KK, Goodell MA: Hematopoietic, vascular and cardiac fates of bone marrow-derived stem cells. Gene Ther 2002, 9:648-652.

30. Orlic D, Kajstura J, Chimenti S, Jakoniuk I, Anderson SM, Li B, Pickel J, McKay R, Nadal-Ginard B, Bodine DM, Leri A, Anversa P: Bone marrow cells regenerate infarcted myocardium. Nature 2001, 410:701-705.

31. Orlic D, Kajstura J, Chimenti S, Limana F, Jakoniuk I, Quaini F, Nadal-Ginard B, Bodine DM, Leri A, Anversa P: Mobilized bone marrow cells repair the infarcted heart, improving function and survival. Proc Natl Acad Sci U S A 2001, 98:10344-10349.

32. Kocher AA, Schuster MD, Szabolcs MJ, Takuma S, Burkhoff D, Wang J, Homma S, Edwards NM, Itescu S: Neovascularization of ischemic myocardium by human bone-marrow-derived angioblasts prevents cardiomyocyte apoptosis, reduces remodeling and improves cardiac function. Nat Med 2001, 7:430-436

33. Asahara T, Murohara T, Sullivan A, Silver M, van der Zee R, Li T, Witzenbichler B, Schatteman G, Isner JM: Isolation of putative progenitor endothelial cells for angiogenesis. Science 1997, 275:964-967.

34. Shi Q, Rafii S, Wu MH, Wijelath ES, Yu C, Ishida A, Fujita Y, Kothari S, Mohle R, Sauvage LR, Moore MA, Storb RF, Hammond WP: Evidence for circulating bone marrow-derived endothelial cells. Blood 1998, 92:362-367.

35. Takahashi T, Kalka C, Masuda H, Chen D, Silver M, Kearney M, Magner M, Isner $\mathrm{JM}$, Asahara T: Ischemia- and cytokine-induced mobilization of bone marrow-derived endothelial progenitor cells for neovascularization. Nat Med 1999, 5:434-438.

36. Beltrami AP, Barlucchi L, Torella D, Baker M, Limana F, Chimenti S, Kasahara H, Rota M, Musso E, Urbanek K, Leri A, Kajstura J, Nadal-Ginard B, Anversa P: Adult cardiac stem cells are multipotent and support myocardial regeneration. Cell 2003, 114:763-776

37. Martin CM, Meeson AP, Robertson SM, Hawke TJ, Richardson JA, Bates S, Goetsch SC, Gallardo TD, Garry DJ: Persistent expression of the ATP-binding cassette transporter, Abcg2, identifies cardiac SP cells in the developing and adult heart. Dev Biol 2004, 265:262-275.

38. Oh H, Bradfute SB, Gallardo TD, Nakamura T, Gaussin V, Mishina Y, Pocius J, Michael LH, Behringer RR, Garry DJ, Entman ML, Schneider MD: Cardiac progenitor cells from adult myocardium: homing, differentiation, and fusion after infarction. Proc Natl Acad Sci U S A 2003, 100:12313-12318.

39. Cai CL, Martin JC, Sun Y, Cui L, Wang L, Ouyang K, Yang L, Bu L, Liang X, Zhang $X$, Stallcup WB, Denton CP, McCulloch A, Chen J, Evans SM: A myocardial lineage derives from Tbx18 epicardial cells. Nature 2008, 454:104-108.

40. Zhou B, Ma Q, Rajagopal S, Wu SM, Domian I, Rivera-Feliciano J, Jiang D, von 
Gise A, Ikeda S, Chien KR, Pu WT: Epicardial progenitors contribute to the cardiomyocyte lineage in the developing heart. Nature 2008, 454:109-113

41. Segers VF, Lee RT: Stem-cell therapy for cardiac disease. Nature 2008, 451:937-942.

42. Gersh BJ, Simari RD, Behfar A, Terzic CM, Terzic A: Cardiac cell repair therapy: a clinical perspective. Mayo Clin Proc 2009, 84:876-892.

43. Wang F, Guan J: Cellular cardiomyoplasty and cardiac tissue engineering for myocardial therapy. Adv Drug Deliv Rev 2010, 62:784-797.

44. Lipinski MJ, Biondi-Zoccai GG, Abbate A, Khianey R, Sheiban I, Bartunek J, Vanderheyden M, Kim HS, Kang HJ, Strauer BE, Vetrovec GW: Impact of intracoronary cell therapy on left ventricular function in the setting of acute myocardial infarction: a collaborative systematic review and metaanalysis of controlled clinical trials. J Am Coll Cardiol 2007, 50:1761-1767.

45. Dib N, Michler RE, Pagani FD, Wright S, Kereiakes DJ, Lengerich R, Binkley P, Buchele D, Anand I, Swingen C, Di Carli MF, Thomas JD, Jaber WA, Opie SR, Campbell A, McCarthy P, Yeager M, Dilsizian V, Griffith BP, Korn R, Kreuger SK, Ghazoul M, MacLellan WR, Fonarow G, Eisen HJ, Dinsmore J, Diethrich E: Safety and feasibility of autologous myoblast transplantation in patients with ischemic cardiomyopathy: four-year follow-up. Circulation 2005, 112:1748-1755.

46. Menasché P, Hagège AA, Scorsin M, Pouzet B, Desnos M, Duboc D, Schwartz $K$, Vilquin JT, Marolleau JP: Myoblast transplantation for heart failure. Lancet 2001, 357:279-280

47. Marelli D, Desrosiers C, el-Alfy M, Kao RL, Chiu RC: Cell transplantation for myocardial repair: an experimental approach. Cell Transplant 1992, 1:383-390.

48. Reinecke H, Poppa V, Murry CE: Skeletal muscle stem cells do not transdifferentiate into cardiomyocytes after cardiac grafting. J Mol Cell Cardiol 2002, 34:241-249.

49. Suzuki K, Brand NJ, Smolenski RT, Jayakumar J, Murtuza B, Yacoub MH: Development of a novel method for cell transplantation through the coronary artery. Circulation 2000, 102(19 Suppl 3):III359-364.

50. Menasche P: Cellular transplantation: hurdles remaining before widespread clinical use. Curr Opin Cardiol 2004, 19:154-161.

51. Fan Y, Maley M, Beilharz M, Grounds M: Rapid death of injected myoblasts in myoblast transfer therapy. Muscle Nerve 1996, 19:853-860

52. Beauchamp JR, Morgan JE, Pagel CN, Partridge TA: Dynamics of myoblast transplantation reveal a discrete minority of precursors with stem cell-like properties as the myogenic source. J Cell Biol 1999, 144:1113-1122.

53. Huard J, Acsadi G, Jani A, Massie B, Karpati G: Gene transfer into skeletal muscles by isogenic myoblasts. Hum Gene Ther 1994, 5:949-958.

54. Oshima H, Payne TR, Urish KL, Sakai T, Ling Y, Gharaibeh B, Tobita K, Keller BB, Cummins JH, Huard J: Differential myocardial infarct repair with muscle stem cells compared to myoblasts. Mol Ther 2005, 12:1130-1141

55. Sakai T, Ling Y, Payne TR, Huard J: The use of ex vivo gene transfer based on muscle-derived stem cells for cardiovascular medicine. Trends Cardiovasc Med 2002, 12:115-120.

56. Payne TR, Oshima H, Sakai T, Ling Y, Gharaibeh B, Cummins J, Huard J: Regeneration of dystrophin-expressing myocytes in the $\mathrm{mdx}$ heart by skeletal muscle stem cells. Gene Ther 2005, 12:1264-1274.

57. Payne TR, Oshima H, Okada M, Momoi N, Tobita K, Keller BB, Peng H, Huard J: A relationship between vascular endothelial growth factor, angiogenesis, and cardiac repair after muscle stem cell transplantation into ischemic hearts. J Am Coll Cardiol 2007, 50:1677-1684.

58. Deasy BM, Feduska JM, Payne TR, Li Y, Ambrosio F, Huard J: Effect of VEGF on the regenerative capacity of muscle stem cells in dystrophic skeletal muscle. Mol Ther 2009, 17:1788-1798.

59. Tavian M, Zheng B, Oberlin E, Crisan M, Sun B, Huard J, Peault B: The vascular wall as a source of stem cells. Ann N Y Acad Sci 2005, 1044:41-50

60. Crisan M, Deasy B, Gavina M, Zheng B, Huard J, Lazzari L, Péault B: Purification and long-term culture of multipotent progenitor cells affiliated with the walls of human blood vessels: myoendothelial cells and pericytes. Methods Cell Biol 2008, 86:295-309.

61. Zheng B, Cao B, Crisan M, Sun B, Li G, Logar A, Yap S, Pollett JB, Drowley L, Cassino T, Gharaibeh B, Deasy BM, Huard J, Péault B: Prospective identification of myogenic endothelial cells in human skeletal muscle. Nat Biotechnol 2007, 25:1025-1034

62. Crisan M, Yap S, Casteilla L, Chen CW, Corselli M, Park TS, Andriolo G, Sun B, Zheng B, Zhang L, Norotte C, Teng PN, Traas J, Schugar R, Deasy BM, Badylak S, Buhring HJ, Giacobino JP, Lazzari L, Huard J, Péault B: A perivascular origin for mesenchymal stem cells in multiple human organs. Cell Stem Cell 2008,
3:301-313

63. Okada M, Payne TR, Zheng B, Oshima H, Momoi N, Tobita K, Keller BB, Phillippi JA, Péault B, Huard J: Myogenic endothelial cells purified from human skeletal muscle improve cardiac function after transplantation into infarcted myocardium. J Am Coll Cardio/ 2008, 52:1869-1880.

64. Chen CW, Corselli M, Okada M, Crisan M, Tobita K, Péault B, Huard J: The anti-fibrotic and anti-inflammatory potentials of purified human musclederived perivascular cells for the treatment of myocardial infarction. Circulation 2010, 122:A20465.

65. Ciulla MM, Montelatici E, Ferrero S, Braidotti P, Paliotti R, Annoni G, De Camilli E, Busca G, Chiappa L, Rebulla P, Magrini F, Lazzari L: Potential advantages of cell administration on the inflammatory response compared to standard ACE inhibitor treatment in experimental myocardial infarction. J Trans/ Med 2008, 6:30

66. Kinnaird T, Stabile E, Burnett MS, Shou M, Lee CW, Barr S, Fuchs S, Epstein SE: Local delivery of marrow-derived stromal cells augments collateral perfusion through paracrine mechanisms. Circulation 2004, 109:1543-1549.

67. Chen L, Tredget EE, Wu PY, Wu Y: Paracrine factors of mesenchymal stem cells recruit macrophages and endothelial lineage cells and enhance wound healing. PLoS One 2008, 3:e1886.

68. Tang YL, Zhao Q, Qin X, Shen L, Cheng L, Ge J, Phillips MI: Paracrine action enhances the effects of autologous mesenchymal stem cell transplantation on vascular regeneration in rat model of myocardial infarction. Ann Thorac Surg 2005, 80:229-236; discussion 236-237.

69. Qian H, Yang H, Xu W, Yan Y, Chen Q, Zhu W, Cao H, Yin Q, Zhou H, Mao F, Chen $Y$ : Bone marrow mesenchymal stem cells ameliorate rat acute renal failure by differentiation into renal tubular epithelial-like cells. Int J Mol Med 2008, 22:325-332.

70. Balsam LB, Wagers AJ, Christensen JL, Kofidis T, Weissman IL, Robbins RC Haematopoietic stem cells adopt mature haematopoietic fates in ischaemic myocardium. Nature 2004, 428:668-673.

71. Wang L, Deng J, Tian W, Xiang B, Yang T, Li G, Wang J, Gruwel M, Kashour T, Rendell J, Glogowski M, Tomanek B, Freed D, Deslauriers R, Arora RC, Tian G: Adipose-derived stem cells are an effective cell candidate for treatment of heart failure: an MR imaging study of rat hearts. Am J Physiol Heart Circ Physiol 2009, 297:H1020-1031.

72. Santhanam AV, Smith LA, He T, Nath KA, Katusic ZS: Endothelial progenitor cells stimulate cerebrovascular production of prostacyclin by paracrine activation of cyclooxygenase-2. Circ Res 2007, 100:1379-1388.

73. Yoon CH, Hur J, Park KW, Kim JH, Lee CS, Oh IY, Kim TY, Cho HJ, Kang HJ, Chae

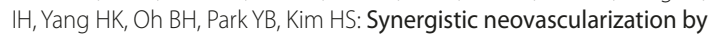
mixed transplantation of early endothelial progenitor cells and late outgrowth endothelial cells: the role of angiogenic cytokines and matrix metalloproteinases. Circulation 2005, 112:1618-1627.

74. Chen J, Park HC, Addabbo F, Ni J, Pelger E, Li H, Plotkin M, Goligorsky MS: Kidney-derived mesenchymal stem cells contribute to vasculogenesis, angiogenesis and endothelial repair. Kidney Int 2008, 74:879-889.

75. Murry CE, Reinecke H, Pabon LM: Regeneration gaps: observations on stem cells and cardiac repair. J Am Coll Cardiol 2006, 47:1777-1785.

76. Matsumoto T, Kuroda R, Mifune Y, Kawamoto A, Shoji T, Miwa M, Asahara T, Kurosaka M: Circulating endothelial/skeletal progenitor cells for bone regeneration and healing. Bone 2008, 43:434-439.

77. Matsumoto T, Mifune Y, Kawamoto A, Kuroda R, Shoji T, Iwasaki H, Suzuki T, Oyamada A, Horii M, Yokoyama A, Nishimura H, Lee SY, Miwa M, Doita M, Kurosaka M, Asahara T: Fracture induced mobilization and incorporation of bone marrow-derived endothelial progenitor cells for bone healing. $J$ Cell Physiol 2008, 215:234-242.

78. Matsumoto T, Kawamoto A, Kuroda R, Ishikawa M, Mifune Y, Iwasaki H, Miwa M, Horii M, Hayashi S, Oyamada A, Nishimura H, Murasawa S, Doita M, Kurosaka M, Asahara T: Therapeutic potential of vasculogenesis and osteogenesis promoted by peripheral blood CD34-positive cells for functional bone healing. Am J Pathol 2006, 169:1440-1457.

79. Urish KL, Vella JB, Okada M, Deasy BM, Tobita K, Keller BB, Cao B, Piganelli JD, Huard J: Antioxidant levels represent a major determinant in the regenerative capacity of muscle stem cells. Mol Biol Cell 2009, 20:509-520

80. Drowley L, Okada M, Beckman S, Vella J, Keller B, Tobita K, Huard J: Cellular antioxidant levels influence muscle stem cell therapy. Mol Ther 2010 18:1865-1873.

81. Hu X, Yu SP, Fraser UL, Lu Z, Ogle ME, Wang JA, Wei L: Transplantation of hypoxia-preconditioned mesenchymal stem cells improves infarcted heart function via enhanced survival of implanted cells and angiogenesis. 
J Thorac Cardiovasc Surg 2008, 135:799-808.

82. Pasha Z, Wang Y, Sheikh R, Zhang D, Zhao T, Ashraf M: Preconditioning enhances cell survival and differentiation of stem cells during transplantation in infarcted myocardium. Cardiovasc Res 2008, 77:134-142.

83. Li W, Ma N, Ong LL, Nesselmann C, Klopsch C, Ladilov Y, Furlani D, Piechaczek C, Moebius JM, Lützow K, Lendlein A, Stamm C, Li RK, Steinhoff G: Bcl-2 engineered MSCs inhibited apoptosis and improved heart function. Stem Cells 2007, 25:2118-2127.

84. Yin M, Pacifici M: Vascular regression is required for mesenchymal condensation and chondrogenesis in the developing limb. Dev Dyn 2001, 222:522-533.

85. Maes C, Stockmans I, Moermans K, Van Looveren R, Smets N, Carmeliet P, Bouillon R, Carmeliet G: Soluble VEGF isoforms are essential for establishing epiphyseal vascularization and regulating chondrocyte development and survival. J Clin Invest 2004, 113:188-199.

86. Gerber HP, Vu TH, Ryan AM, Kowalski J, Werb Z, Ferrara N: VEGF couples hypertrophic cartilage remodeling, ossification and angiogenesis during endochondral bone formation. Nat Med 1999, 5:623-628.

87. Carlevaro MF, Cermelli S, Cancedda R, Descalzi Cancedda F: Vascular endothelial growth factor (VEGF) in cartilage neovascularization and chondrocyte differentiation: auto-paracrine role during endochondral bone formation. J Cell Sci 2000, 113:59-69.

88. Hashimoto S, Creighton-Achermann L, Takahashi K, Amiel D, Coutts RD, Lotz M: Development and regulation of osteophyte formation during experimental osteoarthritis. Osteoarthritis Cartilage 2002, 10:180-187.

89. Ashraf S, Walsh DA: Angiogenesis in osteoarthritis. Curr Opin Rheumatol 2008, 20:573-580

90. Pufe T, Harde V, Petersen W, Goldring MB, Tillmann B, Mentlein R: Vascular endothelial growth factor (VEGF) induces matrix metalloproteinase expression in immortalized chondrocytes. J Pathol 2004, 202:367-374.

91. Pufe T, Petersen W, Tillmann B, Mentlein R: The splice variants VEGF121 and VEGF189 of the angiogenic peptide vascular endothelial growth factor are expressed in osteoarthritic cartilage. Arthritis Rheum 2001, 44:1082-1088.

92. Pfander D, Körtje D, Zimmermann R, Weseloh G, Kirsch T, Gesslein M, Cramer T, Swoboda B: Vascular endothelial growth factor in articular cartilage of healthy and osteoarthritic human knee joints. Ann Rheum Dis 2001, 60:1070-1073.

93. Enomoto H, Inoki I, Komiya K, Shiomi T, Ikeda E, Obata K, Matsumoto H, Toyama Y, Okada Y: Vascular endothelial growth factor isoforms and their receptors are expressed in human osteoarthritic cartilage. Am J Pathol 2003, 162:171-181

94. Brittberg M, Lindahl A, Nilsson A, Ohlsson C, Isaksson O, Peterson L: Treatment of deep cartilage defects in the knee with autologous chondrocyte transplantation. N Engl J Med 1994, 331:889-895.

95. Ochi M, Uchio Y, Kawasaki K, Wakitani S, I wasa J: Transplantation of cartilagelike tissue made by tissue engineering in the treatment of cartilage defects of the knee. J Bone Joint Surg Br 2002, 84:571-578.

96. Visna P, Pasa L, Cizmar I, Hart R, Hoch J: Treatment of deep cartilage defects of the knee using autologous chondrograft transplantation and by abrasive techniques--a randomized controlled study. Acta Chir Belg 2004, 104:709-714.

97. O'Driscoll SW: The healing and regeneration of articular cartilage. J Bone Joint Surg Am 1998, 80:1795-1812.

98. Bentley G, Biant LC, Carrington RW, Akmal M, Goldberg A, Williams AM, Skinner JA, Pringle J: A prospective, randomised comparison of autologous chondrocyte implantation versus mosaicplasty for osteochondral defects in the knee. J Bone Joint Surg Br 2003, 85:223-230.

99. LaPrade RF, Swiontkowski MF: New horizons in the treatment of osteoarthritis of the knee. JAMA 1999, 281:876-878.

100. Wakitani S, Mitsuoka T, Nakamura N, Toritsuka Y, Nakamura Y, Horibe S: Autologous bone marrow stromal cell transplantation for repair of fullthickness articular cartilage defects in human patellae: two case reports. Cell Transplant 2004, 13:595-600

101. Kuroda R, Ishida K, Matsumoto T, Akisue T, Fujioka H, Mizuno K, Ohqushi $\mathrm{H}_{\text {, }}$ Wakitani S, Kurosaka M: Treatment of a full-thickness articular cartilage defect in the femoral condyle of an athlete with autologous bone-marrow stromal cells. Osteoarthritis Cartilage 2007, 15:226-231.

102. Kuroda R, Usas A, Kubo S, Corsi K, Peng H, Rose T, Cummins J, Fu FH, Huard J: Cartilage repair using bone morphogenetic protein 4 and muscle-derived stem cells. Arthritis Rheum 2006, 54:433-442.

103. Hashimoto S, Ochs RL, Komiya S, Lotz M: Linkage of chondrocyte apoptosis and cartilage degradation in human osteoarthritis. Arthritis Rheum 1998 41:1632-1638.

104. Pufe T, Lemke A, Kurz B, Petersen W, Tillmann B, Grodzinsky AJ, Mentlein R: Mechanical overload induces VEGF in cartilage discs via hypoxia-inducible factor. Am J Pathol 2004, 164:185-192.

105. Tanaka E, Aoyama J, Miyauchi M, Takata T, Hanaoka K, Iwabe T, Tanne K: Vascular endothelial growth factor plays an important autocrine/ paracrine role in the progression of osteoarthritis. Histochem Cell Biol 2005 123:275-281

106. Afuwape AO, Kiriakidis S, Paleolog EM: The role of the angiogenic molecule VEGF in the pathogenesis of rheumatoid arthritis. Histol Histopathol 2002, 17:961-972.

107. Matsumoto Y, Tanaka K, Hirata G, Hanada M, Matsuda S, Shuto T, Iwamoto Y: Possible involvement of the vascular endothelial growth factor-Flt-1-focal adhesion kinase pathway in chemotaxis and the cell proliferation of osteoclast precursor cells in arthritic joints. J Immunol 2002, 168:5824-5831.

108. Murakami M, Iwai S, Hiratsuka S, Yamauchi M, Nakamura K, Iwakura Y, Shibuya M: Signaling of vascular endothelial growth factor receptor-1 tyrosine kinase promotes rheumatoid arthritis through activation of monocytes/ macrophages. Blood 2006, 108:1849-1856.

109. Afuwape AO, Feldmann M, Paleolog EM: Adenoviral delivery of soluble VEGF receptor 1 (sFlt-1) abrogates disease activity in murine collageninduced arthritis. Gene Ther 2003, 10:1950-1960.

110. De Bandt M, Ben Mahdi MH, Ollivier V, Grossin M, Dupuis M, Gaudry M, Bohlen P, Lipson KE, Rice A, Wu Y, Gougerot-Pocidalo MA, Pasquier C: Blockade of vascular endothelial growth factor receptor I (VEGF-RI), but not VEGF-RII, suppresses joint destruction in the K/BxN model of rheumatoid arthritis. J Immunol 2003, 171:4853-4859.

111. Matsumoto T, Cooper GM, Gharaibeh B, Meszaros LB, Li G, Usas A, Fu FH, Huard J: Cartilage repair in a rat model of osteoarthritis through intraarticular transplantation of muscle-derived stem cells expressing bone morphogenetic protein 4 and soluble Flt-1. Arthritis Rheum 2009, 60:1390-1405.

112. Kubo S, Cooper GM, Matsumoto T, Phillippi JA, Corsi KA, Usas A, Li G, Fu FH, Huard J: Blocking vascular endothelial growth factor with soluble Flt-1 improves the chondrogenic potential of mouse skeletal muscle-derived stem cells. Arthritis Rheum 2009, 60:155-165.

113. Day CS, Kasemkijwattana C, Menetrey J, Floyd SS Jr, Booth D, Moreland MS, Fu $\mathrm{FH}$, Huard J: Myoblast-mediated gene transfer to the joint. J Orthop Res 1997, 15:894-903.

114. Gelse K, Brem M, Klinger P, Hess A, Swoboda B, Hennig F, Olk A: Paracrine effect of transplanted rib chondrocyte spheroids supports formation of secondary cartilage repair tissue. J Orthop Res 2009, 27:1216-1225.

115. Peng H, Usas A, Gearhart B, Olshanski A, Shen HC, Huard J: Converse relationship between in vitro osteogenic differentiation and in vivo bone healing elicited by different populations of muscle-derived cells genetically engineered to express BMP4. J Bone Miner Res 2004, 19:630-641.

116. Shen HC, Peng H, Usas A, Gearhart B, Fu FH, Huard J: Structural and functional healing of critical-size segmental bone defects by transduced muscle-derived cells expressing BMP4. J Gene Med 2004, 6:984-991.

117. Peng H, Usas A, Gearhart B, Young B, Olshanski A, Huard J: Development of a self-inactivating tet-on retroviral vector expressing bone morphogenetic protein 4 to achieve regulated bone formation. Mol Ther 2004, 9:885-894

118. Blanke M, Carl HD, Klinger P, Swoboda B, Hennig F, Gelse K: Transplanted chondrocytes inhibit endochondral ossification within cartilage repair tissue. Calcif Tissue Int 2009, 85:421-433.

119. Conboy IM, Conboy MJ, Wagers AJ, Girma ER, Weissman IL, Rando TA: Rejuvenation of aged progenitor cells by exposure to a young systemic environment. Nature 2005, 433:760-764.

120. Deasy BM, Lu A, Tebbets JC, Feduska JM, Schugar RC, Pollett JB, Sun B, Urish $\mathrm{KL}$, Gharaibeh BM, Cao B, Rubin RT, Huard J: A role for cell sex in stem cellmediated skeletal muscle regeneration: female cells have higher muscle regeneration efficiency. J Cell Biol 2007, 177:73-86.

121. Corsi KA, Pollett JB, Phillippi JA, Usas A, Li G, Huard J: Osteogenic potential of postnatal skeletal muscle-derived stem cells is influenced by donor sex. J Bone Miner Res 2007, 22:1592-1602

122. Perez-Izarbe M, Agbulut O, Pelacho B, Ciorba C, San Jose-Eneriz E, Desnos M, Hagège AA, Aranda P, Andreu EJ, Menasché P, Prósper F: Characterization of the paracrine effects of human skeletal myoblasts transplanted in infarcted myocardium. Eur J Heart Fail 2008, 10:1065-1072.

123. Agbulut O, Vandervelde S, Al Attar N, Larghero J, Ghostine S, Léobon B, 
Robidel E, Borsani P, Le Lorc'h M, Bissery A, Chomienne C, Bruneval P, Marolleau JP, Vilquin JT, Hagège A, Samuel JL, Menasché P: Comparison of human skeletal myoblasts and bone marrow-derived CD133+ progenitors for the repair of infarcted myocardium. J Am Coll Cardiol 2004, 44:458-463.

124. He T, Smith LA, Harrington S, Nath KA, Caplice NM, Katusic ZS: Transplantation of circulating endothelial progenitor cells restores endothelial function of denuded rabbit carotid arteries. Stroke 2004, 35:2378-2384.

125. Togel F, Weiss K, Yang Y, Hu Z, Zhang P, Westenfelder C: Vasculotropic, paracrine actions of infused mesenchymal stem cells are important to the recovery from acute kidney injury. Am J Physiol Renal Physiol 2007, 292:F1626-1635

126. Wegener B, Schrimpf FM, Bergschmidt P, Pietschmann MF, Utzschneider S MilzS, Jansson V, Müller PE: Cartilage regeneration by bone marrow cellsseeded scaffolds. J Biomed Mater Res A 2010, 95:735-740.

127. McCarty RC, Xian CJ, Gronthos S, Zannettino AC, Foster BK: Application of autologous bone marrow derived mesenchymal stem cells to an ovine model of growth plate cartilage injury. Open Orthop J 2010, 4:204-210.

128. Toghraie FS, Chenari N, Gholipour MA, Faghih Z, Torabinejad S, Dehghani S, Ghaderi A: Treatment of osteoarthritis with infrapatellar fat pad derived mesenchymal stem cells in rabbit. Knee 2010, 18:71-75.
129. Wang CZ, Chen SM, Chen CH, Wang CK, Wang GJ, Chang JK, Ho ML: The effect of the local delivery of alendronate on human adipose-derived stem cell-based bone regeneration. Biomaterials 2010, 31:8674-8683.

130. Cohen S, Leshansky L, Zussman E, Burman M, Srouji S, Livne E, Abramov N, Itskovitz-Eldor J: Repair of full-thickness tendon injury using connective tissue progenitors efficiently derived from human embryonic stem cells and fetal tissues. Tissue Eng Part A 2010, 16:3119-3137.

131. Murphy JM, Fink DJ, Hunziker EB, Barry FP: Stem cell therapy in a caprine model of osteoarthritis. Arthritis Rheum 2003, 48:3464-3474

132. Horwitz EM, Prockop DJ, Fitzpatrick LA, Koo WW, Gordon PL, Neel M, Sussman M, Orchard P, Marx JC, Pyeritz RE, Brenner MK: Transplantability and therapeutic effects of bone marrow-derived mesenchymal cells in children with osteogenesis imperfecta. Nat Med 1999, 5:309-313.

doi:10.1186/scrt72

Cite this article as: Gharaibeh B, et al:: Terminal differentiation is not a major determinant for the success of stem cell therapy - cross-talk between muscle-derived stem cells and host cells. Stem Cell Research \& Therapy 2011, 2:31 